\title{
Sistem Bretton Woods dalam Perspektif Maqasid Syariah: Studi Kebijakan Ekonomi Politik Internasional (1944-1971)
}

\author{
Ayif Fathurrahman \\ Universitas Muhammadiyah Yogykarta, \\ Email: Ayief_ospp@yahoo.com
}

\begin{abstract}
Abstrak:
This article try to explain Bretton Woods System in maqasid shariah perspective. In maqashid al-sharia's perspective, the instability of the global economy threatens the existence of al-kulliyât al-khams which must be protected. The Bretton Woods system is the right economic agreement to be established as a system that regulates the international economy (1944-1971). This article also try to explain that the International islamic political economy of is a necessity. Islam as a value, must be internalized in every decision and policy that concerns the lives of many people. International political economy is in a very strategic position to determine policies to achieve global stability and prosperity. The Bretton Woods system can be an "inspired system" that can be a consideration for formulating the direction and strategy of the International Islam political economy. In addition to the gold standard being one of the several Bretton Woods agreements and the stability of exchange rates with the implementation of fixed rate systems, the regularity of international trade and the amount of international funds to reconstruct development in war-affected countries is the highest cause of global economic growth in the history of the global economy.

[Artikel ini mencoba menjelaskan Sistem Bretton Woods dalam perspektif maqasid syariah. Dalam perspektif maqasid syariah, ketidakstabilan ekonomi global mengancam keberadaan al-kulliyat al-khams yang harus dilindungi. Sistem Bretton Woods salah satu dari kesepakatan ekonomi yang tepat untuk membangun sistem ekonomi internasional (19441971). Artikel ini juga mencoba menjelaskan bahwa ekonomi politik Islam Internasional adalah suatu keniscayaan. Islam sebagai value, harus terinternalisasi di dalam setiap decision dan policy yang menyangkut hajat hidup orang banyak. Ekonomi politik internasional menjadi posisi yang sangat strategis untuk menentukan kebijakan demi tercapainya stabilitas dan kemaslahatan global. Sistem Bretton Woods bisa menjadi sebuah "the inspired system" yang bisa menjadi pertimbangan untuk merumuskan arah dan strategi ekonomi politik Islam Internasional. Selain gold standard menjadi salah satu kesepakatan bretton woods dan stabilitas nilai tukar dengan diterapkannya fixed rate system, keteraturan perdagangan internasional dan banyaknya bantuan dana internasional untuk merekontruksi pembangunan di negara-negara korban perang menjadi penyebab lajunya pertumbuhan ekonomi global tertinggi sepanjang sejarah.]
\end{abstract}

Kata Kunci: Bretton Woods; Maqasid; Ekonomi politik; Internasional. 


\section{PENDAHULUAN}

Krisis keuangan global yang terjadi pada tahun 2008 sangat terkait erat dengan kondisi perekonomian Amerika yang sedang mengalami instabilitas. Krisis keuangan yang terjadi di Amerika Serikat telah berkembang menjadi masalah serius. Gejolak perekonomian yang terjadi di Amerika Serikat telah mempengaruhi stabilitas ekonomi di beberapa kawasan. Keterbukaan ekonomi antarnegara, memungkinkan terjadinya resesi di suatu Negara untuk mengarah dan mempengaruhi Negara lainnya.

Dalam sejarah krisis keuangan global, tercatat bahwa stabilitas ekonomi global telah tergoncang berkali-kali. Amerika Serikat sendiri pernah mengalami goncangan luar biasa pada tahun 1929 yang dikenal dengan "The Great Depression" atau "The Black Thusday".1 Sepanjang abad 20 telah terjadi lebih dari 20 kali krisis besar yang melanda banyak Negara. Fakta ini menunjukkan bahwa secara rata-rata, setiap 5 tahun sekali telah terjadi krisis finasial hebat yang mengakibatkan penderitaan bagi ratusan juta umat manusia. ${ }^{2}$

Namun demikian, sekitar tahun 1950-1972, ekonomi global menunjukkan stabilitas yang relatif baik, karena pada periode ini ekonomi global relatif stabil. Menurut catatan Sjamsul, ${ }^{3}$ keadaan ini merupakan pengaruh dari diberlakukannya Bretton Woods Agreements, yang mengeluarkan regulasi di sektor moneter relatif lebih ketat dan tetap (Fixed Exchange Rate Regime). Di samping itu, IMF pada awalnya masih memainkan perannya dalam mengatasi anomali-anomali keuangan global. Regulasi di perbankan dan di sektor keuangan pada umumnya, serta penerapan renzim nilai tukar tetap membuat sektor keuangan dunia menjadi stabil dan terkendali.

Namun pada tahun 1971, kesepakatan Bretton Woods mulai terusik dengan mekanisme bunganya yang tak dapat dibendung, sehingga menimbulkan kesulitan-kesulitan dalam mempertahankan nilai tukar fixed exchange rate ini. Berbagai upaya dilakukan untuk mempertahankannya, seperti dibentuknya kesepakatan Smithsonian walaupun hanya bertahan 2-3 tahun saja. ${ }^{4}$ Akhirnya pada tanggal 15 Agustus 1971 Amerika Serikat melakukan demoneterisasi emas yang menandai berakhirnya sistem Bretton Woods. ${ }^{5}$ Sejak saat itu dunia menganut sistem nilai tukar mengambang terkendali (managed floating), yang kemudian diterapkan dengan uang kertas (fiat money) tanpa didasarkan dengan nilai emas.

Seiring dengan berjalanannya waktu, full fledged managed money standard memunculkan berbagai goncangan kondisi perekonomian global, sehingga pada gilirannya mendatangkan berbagai opsi untuk mengakhiri sistem ini sebagai sistem moneter internasional. Rontoknya sistem fiat money yang diusung oleh Amerika Serikat dalam tsunami finansial global membangkitkan kembali desakan untuk dilakukannya perombakan

\footnotetext{
1Thomas Johnston, The Depression Years, dikutip dari http://library.thinkquest.org/ 3483/Right/gd.html, diakses tanggal 5 April 2010. Peristiwa ini memunculkan aliran Keynes yang menggantikan aliran klasik (Adam Smith, dkk). Penjelasan serupa, juga terdapat pada buku karya Rivai, Veithzal dan Andi Buchari, Islamic Economic: Ekonomi Syari'ah bukan Opsi tetapi Solusi, Jakarta: Bumi Aksara, 2009, 301.

${ }^{2}$ Roy Davies dan Glyn Davies, A History of Money from Ancient Time to Present Day, New York: Oxport University Press, 1996, 13.

3 Sjamsul Arifin Wibisono, Charles P.R. Joseph, Shinta Sudrajat, IMF dan Stabilitas Keuangan Negara: Suatu Tinjauan Kritis, Jakarta: PT Elex Media Kompotindo, 2007, 11.

${ }^{4}$ Michael D. Bordo and Owen F. Humpage, Federal Reserve Policy and Bretton Woods, Federal Reserve Bank of Dallas Globalization and Monetary Policy Institute Working Paper No. 206 http://www.dallasfed.org/assets/documents/institute/wpapers/2014/0206.pdf

5 Tanpa ada alasan yang jelas, tiba-tida Presiden Richard Nixon yang dibantu oleh Menteri Keuangan George Shultz, William Simon dan Paul Volcker, AS membatalkan sebagian kesepakatan Bretton Wood itu secara sepihak, khususnya aturan tentang kurs mata uang.
} 
radikal dan desain ulang terhadap bangunan asrsitek sistem finansial global guna mencegah terulangnya krisis yang sama pada masa mendatang. ${ }^{6}$

Di antara tokoh yang paling kencang menyuarakan dan agresif mengupayakan dukungan dari negara-negara lain adalah Perdana Menteri Inggris Gordon Brown dan Perdana Menteri Perancis Nicolas Sarkozy.7 Sarkozy bersama pemimpin Eropa lainnya berhasil mendesak Presiden AS, pada saat itu masih George W Bush untuk melangsungkan pertemuan darurat membahas gagasan tersebut, pada fourm G-20 di Washington, pada tanggal 15 November 2008.8 Gagasan mereformasi sistem finansial global juga mendapat dukungan kuat dari para pemimpin negara Asia dan Eropa yang hadir pada Konferensi Tingkat Tinggi Asia-Eropa (ASEM) di Beijing, pada tanggal 24-25 Oktober 2008. ${ }^{9}$

Terlepas apakah Bretton Woods akan bisa direalisasikan kembali atau tidak, jelas gagasan ini merupakan respon atas full fledged managed money standard yang secara mutlak tak ada hubungannya dengan emas, yang selama ini diterapkan dan banyak memunculkan masalah perekonomian global.

Sementara itu, dalam Islam, kata dzahab yang berarti emas disebut dalam al-Qur'an sebanyak 8 kali. Bahkan Allah memberikan ancaman kepada orang yang menimbunnya, karena tidak memanfaatkannya sebagai proses stabilisasi ekonomi. Sistem Bretton Woods yang menerapkan sistem gold standard, dinilai cukup berhasil dan mempunyai pengaruh positif dalam menunjang tercapainya peningkatan pertumbuhan ekonomi, perdagangan dan stabilitas keuangan internasional pascaperang dunia II.

Pada titik inilah pentingnya kajian sistem Bretton Wood dalam perspektif Maqashid al-Syariah sebagai bagian daripada proses pemahaman yang komprehensif terhadap ekonomi politik islam yang berorientasi pada stabilitas dan kemaslahatan ekonomi global.

\section{Selayang Pandang Sistem Bretton Woods}

Dalam buku Managing the World Economy Fifty years after Bretton Woods, Kenen (1994) mencoba mendefinsikan secara umum sistem Bretton Woods. Menurutnya, Sistem Bretton Woods merupakan kerangka kelembagaan yang diciptakan untuk membimbing seluruh ekonomi dunia pada akhir perang dunia kedua. ${ }^{10}$ Lebih rinci Kotz (1994) mendefiniskan sistem Bretton Woods dengan satu perangkat moneter internasional, perdagangan, dan hubungan investasi dengan menggunakan standar emas dan di -back up dengan mata uang US Dollar, bebas dipertukarkan pada kurs tetap, dan ekonomi dunia yang terbuka. ${ }^{11}$

\footnotetext{
${ }^{6}$ Lihat “Menghidupkan kembali Bretton Woods”, Kompas, 31 Oktober 2008.

7 Menurut PM Inggris, Gordon Brown, bahwa sekarang adalah saarnya dunia membuat sebuah sistem keuangan internasional yang baru, dikutip dari https://tekno.kompas.com/read/2008/10/17/04465814/eropa.usulkan.bretton.woods.ii?page=all diakses tanggal 19 Maret 2019.

8 Wacana menghidupkan kembali sistem Bretton Wood bukan baru kali pertama muncul. Hampir setiap kali krisis besar terjadi, wacana ini muncul dan kemudian tenggalam dan terlupakan lagi. Pada tahun 1982, gagasan ini dilontarkan oleh Menkeu AS Donald Regan. Pada tahun 1985 oleh Presiden Perancis Francois Mitterand, ketika Perancis dilanda tiga devaluasi Frnac. Dan di ambang krisis finansial Asia 1997-1998, nostalgia Bretton Woods berusaha kembali dibangkitkan oleh rezim pemerintahan Inggris pasca Thatcher. lihat, "Menghidupkan Kembali Sistem Bretton Woods", Kompas, 31 Oktober 2008.

9 Daniri, "Ekonomi Syariah, Bretton Wods, KTT ASEM, dan AS", Republika, 3 Nopember 2008.

10 Peter B. Kenen, Managing the World Economy Fifty years after Bretton Woods, Washington, Institute for International Economic, 1994, 343.

${ }_{11}$ David M. Kotz, Terrence McDonough, and Michael Reich. Social Stuctures of Accumulation: The Polical Economy of Growth and Crisis., Cambridge : Cambridge University Press, 1994, 62.
} 
Dalam kamus ekonomi internatioanl, mencoba untuk melengkapi definisi di atas, menyebutkan bahwa sistem Bretton Woods adalah sistem tukar tetap dengan fluktuasi yang terkendali, di mana setiap anggota Dana Moneter Internasional (IMF) menetapkan paritas khusus untuk mata uangnya relatif terhadap emas atau dolar, serta perubahan harga mata uang Negara anggota terhadap USD tidak boleh melebihi $1 \%$ dari harga parity yang ditetapkan. ${ }^{12}$

Sejarah Sistem Bretton Woods bermula sekitar tahun 1930-an, dimana dunia sedang mengalami kekacuan moneter akibat perang Dunia I. Tatanan ekonomi internasional telah mengalami desintegrasi sehingga menciptakan kekacuan nilai tukar yang bebas mengambang (clean and dirty), devaluasi yang berkompetensi, pengendalian pertukaran mata uang, kendala perdagangan, perang ekonomi dan moneter internasional yang terjadi antarmata uang-mata uang dan blok-blok mata uang. Perdagangan dan investasi internasional dapat dikatakan telah macet total, perdagangan yang dilakukan melalui kesepakatan barter antarpemerintah saling berkompetensi dan berkonflik satu sama lain. ${ }^{13}$

Pengalaman pahit di atas, yang menimpa perekonomian dunia setelah berakhirnya Perang Dunia II membawa dampak yang cukup berarti bagi sikap masyarakat dunia terhadap perekonomian global. Ini tercermin antara lain dari terbentuknya sistem moneter dunia, yaitu Sistem Bretton Wood yang memiliki masa penggunaan dari tahun 1944 sampai 1971.14 Konferensi Bretton Wood dihadiri oleh wakil-wakil 44 negara dan diselenggarakan pada tahun 1944 di Bretton Woods, New Hampshire, Amerika Serikat. Pada awalnya mempunyai 30 negara anggota pada tahun 1945 dan sampai pada akhir tahun 60-an mencapai lebih dari 180 negara anggota.

Kesediaan Negara-negara anggota untuk mengaitkan mata uangnya dengan dollar AS disebabkan oleh kepercayaan mereka pada besarnya cadangan emas AS (pada saat itu senilai lebih dari USD 20 miliar) yang digunakan untuk mem-back up dollar AS. Pada saat itu emas dinilai sebesar USD 35 per ons, sehingga Negara-negara anggota dapat menukar mata uangnya dengan emas setara dengan nilai tersebut. ${ }^{15}$ Posisi AS sebagai kekuatan hegemoni dunia dimanfaatkan untuk berperan sebagai "lender of the last resort" (penyandang dana dalam keadaan darurat). Karena kredibilitas Dollar AS sebagai mata uang internasional sangat tinggi, maka AS (cadangan devisa yang sangat besar) berperan besar dalam menjamin stabilitas nilai tukar mata uang dunia pada waktu itu. ${ }^{16}$

Dari perjanjian Bretton Wood tersebut, kemudian diperkenalkan sebuah konsep mengenai sistem nilai tukar tetap (fixed exchange rate) yang diyakini oleh para ahli pada waktu itu dapat memberikan kepastian dan stabilitas bagi kegiatan perdagangan dan

\footnotetext{
12 Edward G. Hinkelman. Dictionary of International Trade. $6^{\text {th }}$ Edition, Calfornia, World Trade Press, 2005, 27.

13 Murray N. Rothbard, Apa yang Dilakukan Pemerintah terhadap Uang kita : Sebuah Pengantar Komprehensif Ekonomi Uang dari Mazhab Austria; terjemahan dan pengantar : Sukasah Syahdan; Edisi I, Jakarta : Granit, 2007, 89.

14 Pasca perang dingin perdebatan-perdebatan di tingkatan internasional tidak lagi menyangktu bagaimana meredekan ketegangan antara kaum liberal dengan kaum sosialis/Marxis. Akan tetapi Perdebatan saat ini menyangkut cara yang efektif untuk mengelola ekonomi Negara bangsa dan sejauh mana peran Negara dalam aktivitas ekonomi. Perdebatan ini melahirkan paham Keynesianisme pada satu sisi, dan liberalisme di sisi lain. Bagi kamu Keynesian, Negara diperlukan dalam rangka mendorong pertumbuhan ekonomi. Dari pemikiran Keynesian ini lahirlah the Bretton Wood Sistem yang memperoleh kejayaannya selama dua decade. Sementara bagi kalangan liberal, atau yang kemudian seirng disebut dengan kaum neoliberal, campur tangan Negara hanya akan menimbulkan distorsi dan membuat ekonomi dunai tidak dapat berjalan secara efektif dan efesien. Baca lebih lanjut, Budi Winarno, Pertarungan Negara dan Pasar, Yogyakarta : MedPress, 2009, 116-117.

${ }^{15}$ Sjamsul Arifin Wibisono, dkk, IMF dan Stabilitas Keuangan Negara : Suatu Tinjauan Kritis, 1-2.

16 Bob Sugeng Hadiwinata, Politik Bisnis Internasional, Yogyakarta: Kanisius, 2002, 175.
} 
Sistem Bretton Woods dalam Perspektif Maqasid Syariah: Studi Kebijakan Ekonomi Politik Internasional (1944-1971)

investasi dalam bisnis internasional. ${ }^{17}$ Dalam fixed exchange rate sistem ini, Negara-negara didorong untuk menentukan nilai mata uangnya terhadap USD secara tetap dengan suatu mekanisme penyesuian. ${ }^{18}$ Penetapan USD sebagai acuan ini sering disebut intervention currency karena fungsinya sebagai jangkar yang diacu mata uang negara lain. Teknik acuan yang digunakan adalah mematok nilai tukar USD terhadap harga emas secara tetap pada nilai tertentu.

Sistem tetap (fixed exchange rate sistem) di dalam Bretton Wood conference ini mempunyai persamaan dengan gold exchange standard di mana memuat ketentuan sebagai berikut:19 Pertama, Amerika Serikat akan menetapkan nilai USD terhadap emas dan bukan mata uang lain; Kedua, Amerika Serikat akan menjual emas dengan harga tetap kepada pemilik atau pemegang resmi dari mata uang USD; Ketiga, tiap Negara anggota menetapkan harga atau nilai tukarnya terhadap emas atau USD. USD menjadi reserves currency - mata uang dunia; dan keempat, perubahan harga mata uang Negara anggota terhadap USD tidak boleh melebihi $1 \%$ dari harga parity yang ditetapkan. Namun, sepanjang masih di bawah $10 \%$ masih dapat dibenarkan. Bila perubahan di atas 10\% harus seizin IMF.

Kesepakatan Bretton Wood merupakan perjanjian internasional parmanen pertama bagi kerjasama antar negara-negara. Berbagai peraturan dan lembaga diajukan untuk menjamin ekonomi dunia yang stabil dan meluas dan sistem pertukaran nilai uang yang tetap dan teratur. ${ }^{20}$

Di samping itu, sistem nilai tukar tetap berdasarkan Bretton Wood agreement ini dimaksudkan untuk meminimalkan ketidakpastian hubungan perdagangan antarnegara sebagai akibat timbulnya fluktuasi nilai tukar yang terlalu besar. Sedangkan mekanisme penyesuian nilai tukar ditujukan untuk mengatasi gejolak temporer yang berakibat pada ketidakseimbangan neraca pembayaran suatu negara. Oleh karena itu, apabila suatu perekonomian dunia memburuk, dan banyak negara yang mengalami ketidaksembangan neraca pembayaran, maka kemungkinan untuk terjadi perang devaluasi sebagaimana terjadi saat depresi ekonomi dunia tahun 1930-an, dapat terhindarkan. Perang devaluasi untuk saling menyelamatkan neraca pembayaran (compatetive devaluations) yang dilakukan banyak negara pada tahun 1930-an ini dikenal sebagai "beggar the neighbors policy". ${ }^{21}$ Oleh karena itulah, dalam rangka mencegah timbulnya persaingan devaluasi di berbagai Negara saat itu, IMF memprakarsai penerapan sistem nilai tukar tetap, dikenal sebagai sistem Bretton wood, yang mana seluruh nilai mata uang Negara dikaitkan dengan dolar AS. ${ }^{22}$

Senada dengan itu, Huntington (1989) menyebutkan bahwa Bretton Wood berfungsi untuk menjamin sistem perdagangan dan pembayaran yang kurang lebih terbuka sekaligus menyediakan perlindungan bagi stabilitas ekonomi dalam negeri melalui dana moneter internasional. ${ }^{23}$

17 Rimsky. K. Judesseno, Sistem moneter dan Perbankan di Indonesia, Jakarta: PT Gramedia Pustaka Utama, 2002, 69.

18 Suherdi Judokusumo, Pengantar Derivatif dalam Moneter Internasional, Jakarta: Cikal Sakti, 2002, 7.

19 Ibid.

${ }^{20}$ Samuel P. Huntington, dkk. Amerika dan Dunia, Jakarta: Yayasan Obor, 1989, 159.

21 Istilah "beggar the neighbors policy digunakan untuk menggambarkan suatu kondisi dimana banyak negara berebut melemahkan nilai mata uangnya untuk mendorong ekspornya. Apabila tindakan devaluasi ini kemudian diikuti secara berantai oleh negara-negara lain dengan melakukan hal yang sama, maka tidak akan ada satu pun negara yang diuntungkan. Sebaliknya negara-negara tersebut akan mengalami kerugian sebagai akibat menciutnya perdaganga internasional. Baca lebih lanjut : Sjamsul Arifin (ed), Bangkitnya Perekonomian Asia Timur Satu Dekade setelah Krisis, Jakarta : PT Elex Media Kompotindo, 2008, 273.

22 Sjamsul Arifin Wibisono, dkk, IMF dan Stabilitas Keuangan Negara : Suatu Tinjauan Kritis, 3.

${ }^{23}$ Samuel P. Huntington, dkk. Amerika dan Dunia, 158. 
Pernyataan di atas didukung dengan pernyataan Kindlebelger (1973) yang menyebutkan bahwa sistem Bretton Wood sangat efektif dalam mengontrol konflik dan dalam rangka meraih tujuan-tujuan bersama yang telah dibuat oleh negara-negara bangsa. Menurut Kindlebelger (1973), dasar politik sistem Bretton Wood ini ditemukan dalam koinsidensi tiga kondisi, yaitu kosentrasi kekuasaan dalam sejumlah kecil negara, adanya sekolompok kepentingan bersama dari negara-negara tersebut dan kehadiran kekuatan dominan yang rela menjalankan peran kepemimpinan. ${ }^{24}$

Sebagai tindak lanjut perjanjian tersebut, kemudian dibentuk tiga lembaga moneter internasional, yaitu Internasional Monetery Fund (IMF), ${ }^{25}$ Internasional Bank for Recontruction and Development, yang biasa disebut dengan IBRD dan sering pula disebut World Bank, ${ }^{26}$ dan Internasional Trade Organization yang biasa disebut dengan IT0,27 telah berkembang menjadi Organisasi Perdagangan Dunia (World Trade Organization-WTO). ${ }^{28}$ Di dalam perjanjian IMF, para anggota diwajibkan untuk mematuhi beberapa peraturan sebagai berikut : ${ }^{29}$ 1) Mata uang dalam katagori hard currency harus mengaitkan dan dikonversikan dengan seberat terntentu emas (gold exchange standard). 2) Mata uang dalam katagori soft currency harus dikaitkan dengan hard currency, sehingga secara tidak langsung semua mata uang terkait dan convertible dengan emas. Sistem ini selanjutnya lebih dikenal dengan sebutan pegged exchange rate sistem yang banyak diminati oleh Negara-negara berkembang. 3) Jika terjadi defisit neraca pembayaran (balance of payment/ BOP) di antara anggota IMF, maka Negara tersebut dapat meminta bantuan dalam bentuk special drawing right (SDR), yaitu semacam uang giral internasional yang lebih dikenal dengan sebutan gold paper money yang dikeluarkan oleh IMF. Maksud dan tujuan bantuan tersebut:

a. Agar setiap dari anggota IMF terhindar dari perbuatan mendevaluasi mata uangnya;

b. Diharapkan nilai tukar antara Negara-negara anggota IMF tetap stabil;

c. Kalaupun terjadi fluktuasi nilai tukar, diharapkan hanya berkisar antara $1 \%$ sampai dengan $2,5 \%$ di atas atau dibawah kurs yang berlaku resmi.

\section{Pengaruh Sistem Bretton Wood terhadap Stabilitas Ekonomi Dunia}

Tidak jauh sebelum sistem Bretton Woods diterapkan, resesi perekonomian global yang disebut Great Depression pada tahun 1929-1930-an telah mewarnai persoalan ekonomi global. Resesi ini berdampak pada tingginya persentase perlindungan perdagangan berupa bea masuk dan kuota serta munculnya hambatan lainnya. Amerika Serikat ditandai sebagai

\footnotetext{
24 Charles. P, Kendleberger, The World in Depression 1929-1939, Berkeley: Calif, University of California Press, $1973,23$.

25 IMF diberi tugas untuk mempromosikan perdagangan dunia dengan menetapkan aturan-aturan untuk menjaga kurs tetap dan dengan memberikan pinjaman bagi Negara-negara yang mengalami kesulitan nercaya pembayaran. Sebagai bagian dari memonitor kepatuhan Negara anggota terhadap aturan-aturannya, IMF juga melakukan tugasnya untuk mengumpulkan dan menstandarisasi data ekonomi internasional.

${ }^{26}$ Bank dunia memberikan pinjaman jangka panjang untuk membantu Negara-negara berkembang membangun waduk, jalan, dan modal fisik lainnya yang akan berkontribusi bagi pengembangan ekonomi mereka. Dana untuk pinjaman-pinjaman ini diperoleh khususnya dengan menerbitkan obligasi bank dunia, yang dijual di pasar modal Negara-negara maju.

27 Iswardono, Uang dan Bank, Yogyakarta: BPFE, 1996, 37.

28 WTO ditetapkan untuk memonitor aturan-aturan untuk melaksanakan perdagangan antarnegara (tarif dan kuota).

${ }^{29}$ Rimsky. K. Judesseno, Sistem moneter dan Perbankan di Indonesia, Jakarta: PT Gramedia Pustaka Utama, 2002, 70.
} 
pihak yang menerapkan hambatan perdagangan secara masif melalui apa yang disebut the Smoot-hawley Tariff Act pada tahun 1930.30

Dalam rangka menanggapi persoalan di atas, diberlakukan konsesi moneter internasional dengan lahirnya Sistem Bretton Woods. Secara lebih rinci, Halwani (2002) menyebut tujuan dasar disepakatinya Sistem Bretton Woods ${ }^{31}$, antara lain untuk meningkatkan jumlah cadangan negara yang memungkinkan negara tersebut mengatasi depresi tanpa melakukan kebijakan deflasi, devaluasi, dan pembatasan impor. Baik devaluasi dan pembatasan impor akan menimbulkan lingkaran setan yang akan membantu suatu negara yang bersifat sementara dan akan memperburuk keadaan dalam jangka panjang Kedua, untuk memperbaiki posisi ketidakseimbangan neraca pembayararan, ide Keynes adalah untuk menciptakan mekanisme internasional dengan memberikan cara yang baik untuk memperbaiki ketidakseimbangan dalam posisi neraca pembayaran. Hasil penelitian yang ada menunjukkan bahwa upaya suatu negara dalam menggulangi ketidakseimbangan neraca pembayaran adalah melakukan devaluasi. Keynes melemparkan ide untuk mendirikan bank sentral yang dapat memberikan kredit dengan skala dunia, seperti yang dilakukan bank-bank sentral di tiap negara. ${ }^{32}$

Dengan demikian, sampai titik ini, konferensi Bretton Woods merupakan cerminan dari kepedulian para pengambil kebijakan di bidang ekonomi yang merasakan betapa perkembangan hubungan ekonomi antar negara selama periode di tengah terjadinya Perang Dunia menuju ke arah yang tidak dikehendaki.33

Selama era Bretton Wood, interaksi ekonomi internasional, walaupun dibatasi namun tumbuh dengan signifikan. Di awal-awal tahun Bretton Woods diterapkan, beberapa negara sedang memulihkan stabilitas perekonomian nasional setelah dilanda kehancuran (divastation) sebagai dampak dari meletusnya perang. Pasca-Perang Dunia II, pertumbuhan ekonomi sangat luar biasa. Periode pascaperang hingga pertengahan tahun 1970-an disebut sebagai "Zaman Keemasan Kapitalisme" (capitalist Golden Age), yang ditandai dengan berkembangnya negara-negara kesejahteraan. Pelayanan sosial dan kolektif meluas, subsidi terhadap pendidikan, kebudayaan, perumahan, dan kesehatan mendapat perhatian tinggi. Tingkat pengangguran menurun drastis.

Di samping itu, konvergensi pendapatan perkapita menawarkan beberapa penjelasan untuk perilaku perdagangan pada periode pasca-perang. Setelah Perang Dunia Kedua, pendapatan perkapita berkembang pesat dan cenderung untuk berkumpul di seluruh ekonomi industri. Beberapa ekonom berpendapat bahwa konvergensi pendapatan meningkatkan perdagangan. Karena pola permintaan sebagian ditentukan oleh pendapatan,

\footnotetext{
30 Irwin, D.A, "Multilateral and Bilateral Trade Policies in the World Trading System : An Historical Perspective", in J. de Melo and A. Panagariya (eds), new Dimensions in Regional Integration, Cambridge: Cambridge University Press, 1993, dalam Cyrillus Harinowo, IMF Penanganan Krisis \& Indonesia Pasca-IMF, 77.

31 Halwani, Hendra. Ekonomi Internasional \& Globalisasi Ekonomi. Edisi Pertama, Bogor: Ghalia Indonesia, 2002, 261.

32 Di sini Keynes berpendapat, negara tidak hanya diharapkan menjaga ketertiban umum berdasarkan perangkat hukum, menyediakan prasarana ekonomi dan sosial yang memadai melakasanakan program pemberantasan kemiskinan dan ketimpangan sosial, tetapi juga secara aktif terlibat langsung dalam investasi dibidang industri seperti semen, pupuk, bahkan juga dibidang perhotelan dan barang-barang konsumsi seperti tekstil, tepung, terigu, dan minyak goreng. Kata Keynes : "Dalam perekonomian yang sedang menurun, pemerintah sebaliknya memberlakukan deficit spending dalam waktu singkat untuk menciptakan lapangan kerja guna menghambat pelarian modal-uang ke luar negeri dan memperketat kontrol terhadap pertukaran mata uang". Baca lebih lanjut dalam Doug Lorimer, Welfare capitalism and neoliberal globalisation, dikutip dalam Coen Husein Pontoh, Akhir Globalisasi : Dari Perdebatan Teori Menuju Gerakan Massa, Jakarta: C-Books, 2003, 40.

${ }^{33}$ Cyrillus Harinowo, IMF Penanganan Krisis \& Indonesia Pasca-IMF, Jakarta: PT Gramedia Pustaka Utama, 2004, 80.
} 
negara-negara dengan tingkat pendapatan yang sama cenderung untuk berdagang lebih banyak dengan satu sama lain. Berdasarkan teori representative demand menunjukkan bahwa volume perdagangan internasional di bawah rezim sistem bretton woods terus meningkat. ${ }^{34}$ Dengan demikian, perdagangan dunia berkorelasi positif dengan kesamaan dalam pendapatan perkapita.

Di samping itu, Bretton Woods bertujuan untuk menghindari peristiwa krisis selama periode floating system dengan memungkinkan fleksibilitas untuk memperbaiki ketidakseimbangan. ${ }^{35}$ Dalam Sistem Nilai Tukar Tetap (Fixed Exchange Rate) nilai tukar mata uang dibuat konstan ataupun hanya diperbolehkan berfluktuasi dalam kisaran yang sempit. Bordo (1993) menyajikan bukti-bukti pada stabilitas Sistem Bretton Woods dengan menggunakan data nilai tukar resmi. Bordo membandingkan tren nilai tukar standar emas dan setelah keruntuhan Bretton Woods pada 1970-an. Tingkat rata-rata terendah dari perubahan untuk nilai tukar nominal terjadi selama periode konversi Bretton Woods dan selama periode standar emas. ${ }^{36}$

\section{Sistem Bretton Wood dalam Tinjauan Maqasid Syariah}

Berakhirnya Perang Dunia II menandai awal dari sebuah era baru bagi perekonomian global. Para pemangku kebijakan semakin memusatkan perdagangan internasional sebagai aspek terpenting bagi pertumbuhan ekonomi. Dengan tertatanya sistem perdagangan dan sistem keuangan internasional sebagai hasil dari Konferensi Bretton Woods, terjadilah perubahan pesat bagi perdagangan dunia. Dalam kerangka baru kerjasama ini, perdagangan internasional berkembang pesat dan konsisten selama 1950-an dan 1960-an. Total nilai ekspor barang dagangan negara-negara non-komunis meningkat dari \$ 53 miliar menjadi \$ 112.3 Billion, pada tingkat pertumbuhan rata-rata lebih dari 6 persen per tahun. Pertumbuhan bahkan lebih cepat pada 1960-an, ketika tingkat tahunan rata-rata volume ekspor meningkat menjadi lebih dari 8 persen. ${ }^{37}$

Tingkat pertumbuhan ini jauh melebihi laju ekspansi perdagangan dunia dalam setengah abad sebelum tahun 1914, periode yang menjadi tuan rumah "globalisasi pertama" yang sangat dibanggakan. Sejak tahun 1973, perdagangan global telah berkembang pada kecepatan rata-rata lambat-lambatnya sekitar 4 persen per tahun. Lebih penting lagi, pada 1950-an dan 1960-an pertumbuhan perdagangan dunia secara konsisten melampaui pertumbuhan output dunia. Sebagai contoh, 1953-1963, perdagangan produk diproduksi meningkat sebesar 83 persen, sedangkan output manufaktur naik hingga 54 persen. ${ }^{38}$ Ada beberapa hal yang dapat menjelaskan perkembangan ini diantaranya: ${ }^{39}$ Pertama, dipergunkannya sistem nilai tukar tetap sebagaimana disepakati oleh Bretton Woods Agreement dan yang kemudian diatur pelaksanaannya oleh IMF membawa stabilitas yang sangat diharapkan bagi terjadinya perdagangan yang marak.

Kedua, diterapkanya sistem perdagangan international melalui perjanjian bersama yang dituangkan dalam General Agreement on Tariffs and Trades. Penerapan sistem ini serta upaya liberalisasi perdagangan melalui berbagai putaran perundingan akhirnya membawa

\footnotetext{
34 Linder, Staffan (1961). An Essay on Trade and Transformation. New York: Wiley.

35 Bordo, Michael D. (1993). "The Bretton Woods International Monetary System: A Historical Overview," in Michael D. Bordo and Berry Eichengreen (eds.), A Retrospective on the Bretton Woods System, Chicago: University of Chicago Press.

36 Bordo, Michael D. (1993). "The Bretton Woods International Monetary System: A Historical Overview..

37 Kenwood and Lougheed (1992), hlm. 286, dan Ashworth (1987), hlm.285. dalam Andrew G. Terborgh, "The Post-War Rise of World Trade: Does the Bretton Woods System Deserve Credit?", Working Paper No. 78/03, Department of Economic History London School of Economics, 2003, 3.

38 Ibid.

${ }^{39}$ Cyrillus Harinowo, IMF Penanganan Krisis \& Indonesia Pasca-IMF, 81-83.
} 
dampak pada keterbukaan perekonomian yang lebih besar pada negara anggota GATT di seluruh dunia. Perkembangan ini membawa pengaruh yang sangt positif bagi perkembangan perdagangan international lebih lanjut.

Senada dengan di atas, penulis sepakat dengan pendapat Spero (1960) mengenai sistem Bretton Woods, dia mengatakan: Peraturan Bretton Woods disediakan bagi sistem nilai tukar mata uang tetap. Para pejabat publik, masih ingat atas apa yang mereka percayai sebagai pengalaman mengerikan dengan nilai tukar mengambang di 1930, menyimpulkan bahwa nilai tukar tetap adalah yang paling stabil dan yang paling kondusif untuk diperdagangkan Peraturan tersebut lebih jauh mendorong suatu sistem yang terbuka, dengan mengikat anggota pada konvertibilitas mata uang mereka masing-masing menjadi mata uang lainnya dan pada perdagangan bebas. ${ }^{40}$

Huntington (1989) juga menyebutkan bahwa Bretton Wood berfungsi untuk menjamin sistem perdagangan dan pembayaran yang kurang lebih terbuka sekaligus menyediakan perlindungan bagi stabilitas ekonomi dalam negeri melalui dana moneter internasional. ${ }^{41}$ Pernyataan ini didukung dengan pernyataan Kindlebelger yang menyebutkan bahwa sistem Bretton Wood sangat efektif dalam mengontrol konflik dan dalam rangka meraih tujuan-tujuan bersama yang telah dibuat oleh negara-negara bangsa. ${ }^{42}$ Pertumbuhan ekonomi global ini dilatarbelakangi dengan kesepakatan gold bulion standard, dengan ketentuan mata uang nasional disetarakan dengan emas. Dalam sejarah Islam, tokoh-tokoh yang mendorong uang harus terikat dengan emas dan perak diantaranya Mujahid, Abu Hanifah, An-Nakha'i, Abu Yusuf, An-Nabhani dan Baqir Sadr.43

Faktor-faktor yang melatarbelakangi terbentuknya Bretton Woods Agreements, sebenarnya berpijak dari pengalaman Perang Dunia I. Sebagaimana yang pernah terjadi, menggambarkan masa yang sangat berat bagi perekonomian dunia. Kebangkitan perekonomian negara-negara yang terlibat perang, seperti peningkatan produksi bahan makanan dan industri, akan membuat produksi global meningkat cepat, jauh melebihi kebutuhan. Fakta membuktikan bahwa pada tahun 1930-an, dunia sedang mengalami kekacuan moneter akibat perang Dunia I. Tatanan ekonomi internasional telah mengalami desintegrasi sehingga menciptakan kekacuan nilai tukar yang bebas mengambang (clean and dirty), devaluasi yang berkompetensi, pengendalian pertukaran mata uang, kendala perdagangan, perang ekonomi dan moneter internasional yang terjadi antarmata uang-mata uang dan blok-blok mata uang (Beggar they neighbor policy). Perdagangan dan investasi internasional dapat dikatakan telah macet total, perdagangan yang dilakukan melalui kesepakatan barter antarpemerintah saling berkompetensi dan berkonflik satu sama lain. Keadaan ini dikenal dengan istilah The Great Depression.

Dengan demikian, terbentuknya Bretton Woods Agreements merupakan kesepakatan tokoh dan ekonom dunia untuk mengantisipasi gejala-gejala yang dapat menghantarkan umat manusia kepada krisis global seperti yang terjadi sebelumnya. Pendek kata, Bretton Woods Agreements pada prinsipnya bertujuan untuk menstabilkan perekonomian dan menciptakan kemaslahatan global.

\footnotetext{
${ }^{40}$ Spero, J.E. Political Realism in International Theory. Cambridge: Cambridge University Press, 1996, 37, dikutip dalam Robert Jackson \& Georg Sorensen, Pengantar Studi Hubungan International. Yogykarta: Pustaka Pelajar, 1999, 230.

41 Samuel P. Huntington, dkk. Amerika dan Dunia, 158.

42 Charles. P, Kendleberger, The World in Depression 1929-1939, 23.

43 Pujiono, Arif. Dinar Dan Sistem Standar Tunggal Emas Ditinjau Menurut Sistem Moneter Islam, Jurnal Dinamika Pembangunan, Vol. 1 No. 2 / Desember 2004: 144 - 152.
} 
Kemaslahatan global menjadi unsur aksiologis (maqasid) ekonomi politik Islam. Menurut Thohir Ibnu Asur, pada prinsipnya semua ajaran syari'ah khususnya Islam datang dengan membawa misi kemaslahatan bagi manusia di dunia dan akhirat. ${ }^{4}$ Dalam konteks maqasidu al-Syari'ah, ${ }^{45}$ bahwa hukum Islam secara kualitatif maupun kuantitatif melindungi kemaslahatan setiap individu di tengah masyarakat yang meliputi aspek agama (hifzu ad-din), jiwa (hifzu an-nafs), keturunan (hifzu an-nasl), akal (hifzu al-'aql), dan harta (hifzu al-mal).46 Konskuensi logis dari prinsip ini telah memberikan pemahaman bahwa dalam konteks instabilitas, krisis, resesi, economic contagion (mafsadah) yang terjadi pada aspek perekonomian adalah satu hal yang kontradiktif., karena bisa berakibat fatal pada ketidakseimbangan, bahkan keberlangsungan kehidupan manusia. Sehingga pada gilirannya dapat mengancam al-kulliyyat al-khams atau adh-dharurat al-khams (lima hal inti) tersebut.

Kemaslahatan dasar di atas telah terguncang dengan guncangan yang sangat hebat, lantaran meletusnya Perang Dunia II. Tataran sosio-ekonomi, terutama stabilitas perekonomian dunia, menjadi tak terkendali dan menimbulkan kekacauan pada sistem moneter keuangan internasional. Keadaan ini memicu gelombang fluktuasi yang besar dan semakin tak terkendali, sehingga mengganggu aktivitas perdagangan global yang berujung pada kemacetan dan kemandekan pertumbuhan ekonomi global. Ketidakseimbangan yang disebabkan oleh kekacauan arus perdagangan (ekspor dan impor) banyak memicu berbagai Negara untuk melakukan devaluasi terhadap mata uang domestiknya. Akhirnya berdampak pada ketidakpastian dalam pembayaran perdagangan internaional (balance of payment).

Kehancuran (divastation) pundi-pundi ekonomi global di atas, jelas akan mengancam keseimbangan kehidupan umat manusia dan melebarkan penderitaan bagi ratusan juta umat manusia di muka bumi ini. Peristiwa Great Depression sebagaimana pernah terjadi pada sekitar tahun 1930, sebagai akibat Perang Dunia I telah menyebabkan terus berlanjutnya kemelaratan, kelaparan, dan kesengsaraan umat manusia di berbagai belahan dunia.

Sebagaimana tujuan didirikannya, Sistem Bretton Wood telah membantu negaranegara korban perang, terutama di wilayah Eropa, untuk segera merekonstruksi infrastruktur dan perekonomiannya yang hancur pascaperang dunia kedua. Sistem Bretton Wood melalui lembaga di bawah naungannya Bank Dunia, telah mendanai proyek-proyek di berbagai negara untuk mengembangkan beberapa hal, seperti pembangunan infrastruktur, pendidikan, kesehatan, pelayanan publik, pengentasan kemiskinan, hingga lingkungan hidup. Pendek kata, kala itu pembangunan lebih diarahkan pada pembangunan manusia pascaperang, sehingga segala bidang yang secara langsung berhubungan dengan kemanusiaan sangat diprioritaskan.

Islam, sebagaimana diyakini oleh para pemeluknya adalah satu sistem nilai yang bersumber dari Allah. Karena itu kebenarannya bersifat absolut, tunggal, eternal, dan universal. ${ }^{47}$ Islam sangat memperhatikan masalah pembangunan ekonomi, namun tetap

\footnotetext{
44 Muhammad Thohir Ibnu Asur, Maqashid al-Syari'ah al-Islamiyah, Tunisia: al-Syirkah Tunisia, 1978, 13.

45 Dalam ushul fiqh, bahasan maqashid syari'ah bertujuan untuk mengetahui tujuan-tujuan yang hendak dicapai oleh perumusnya dalam mensyariatkan hukum. Tujuan hukum ini merupakan salah satu faktor penting dalam melakukan ijtihad. Ulama ushul fiqh mendefinisikan maqashid syari'ah sebagai makna dan tujuan yang dikehendaki syara' dalam mensyariatkan suatu hukum bagi kemaslahatan manusia, baca Ensiklopedi Hukum Islam, Abdul Azis Dahlan (ed), Jakarta: PT Ichtiar Baru Van Hoeve, 1108.

${ }^{46}$ Menurut berbagai pendapat bahwa al-kuliyyah al-khamsah yang telah dirumuskan oleh para ahli fiqh klasik pada masa mereka sudah tidak cukup lagi jika sebatas lima kebutuhan primer tersebut. Sehingga inovasi dalam meletakkan kebutuhan-kebutuhan primer kekinian sebagai maqashid al-syari'ah, seperti hak kebebasan berpendapat, berpolitik, pemilu dan suksesi, hak mendapat pekerjaan, sandang, pangan dan papan, hak mendapat pendidikan, hak pengobatan dan sebagainya, sangat perlu adanya.

47 Dengan kemutlakannya ini, Islam sebagaimana halnya agama dan sistem kepercayaan lainya senantiasa mengasumsikan kemutlakan agar dapat memberikan kepastian sehingga berfungsi sebagai pedoman hidup.
} 
menempatkannya pada persoalan pembangunan yang lebih besar, yaitu pembangunan umat manusia. Fungsi utama Islam adalah membimbing manusia pada jalur yang benar dan arah yang tepat. Semua aspek yang berkaitan dengan pembangunan ekonomi harus menyatu dengan pembangunan umat manusia secara keseluruhan.

Menurut At-Tariqy (1999) bahwa pertumbuhan ekonomi bukan hanya aktivitas produksi material saja. Lebih dari itu, pertumbuhan ekonomi merupakan aktivitas menyeluruh dalam bidang produksi yang terkait erat dengan keadilan distribusi. Pertumbuhan ekonomi bukan hanya diukur dari aspek ekonomi, melainkan aktivitas manusia yang ditujukan untuk pertumbuhan dan kemajuan sisi material dan spiritual manusia sekaligus. ${ }^{48}$

Dalam kaitannya dengan dharûriyah, hemat penulis, stabilitas perekonomian dunia merupakan hal yang dharuri. Sebab instabilitas yang terjadi, terutama pada masa Perang Dunia II ini merupakan suatu momok yang bisa membuat jutaan umat manusia melarat, sengsara, dan hidup dalam kemiskinan, bahkan tak jarang berujung pada kematian. Stabilitas perekonomian pada masa ini merupakan jembatan bagi warga internasional untuk menuju hidup yang lebih baik. Sehingga berdasarkan fakta ini, menurut penulis Sistem Bretton Woods pada masa itu (1944-1973) merupakan wasilah yang menyandang status wajib hukumnya untuk ditetapkan sebagai sistem yang mengatur perekonomian internasional. Dalam keadaan darurat seperti ini, argumentatif istihsan juga dapat digunakan sebagai hujjah. ${ }^{49}$ Karena tujuan utama istihsan adalah menghilangkan kesukaran (raf' al-haraj), menghilangkan kemadharatan dan menarik kemaslahatan baik kemaslahatan tersebut berupa kemaslahatan kategori dharuriyyat, hajjiyyat, maupun tahsiniyyat. .0

Dalam konteks maqashid al-syariah, semakin kacaunya stabilitas perekonomian dunia mengancam eksistensi al-kulliyât al-khams yang harus dilindungi. Pertama, hifdz al-dîn (Perlindungan terhadap keyakinan agama), Islam mengajarkan umat manusia untuk berupaya menjaga akidah. Kedua, hifdz al-nafs (Perlindungan terhadap keselamatan jiwa); Islam mengajarkan untuk memelihara dan menghormati keamanan dan keselamatan diri manusia. Ketiga, hifdz al-áql (Perlindungan terhadap eksistensi akal), akal adalah dimensi paling penting dalam kehidupan manusia. Keempat, Hifdz al-nasl (Perlindungan terhadap keturunan), Islam mengajarkan untuk memelihara dan menghormati sistem keluarga (keturunan). Kelima, Hifdz al mâl (Perlindungan terhadap harta); Islam mengajarkan untuk menjamin perkembangan ekonomi masyarakat yang stabil, menciptakan keseimbangan (equlibrium) yang menghasilkan stabilitas dan tatanan perekonomian yang tangguh, dan terhindar dari krisis.

Karena itu, dapat dimengerti ketika menyangkut al-Sunnah, kajian yang pertama kali dilakukan adalah kritik sanad yang bertujuan untuk mempertegas validitas dan outentisitasnya (tsubut). Universitas dan eternalitas Islam, sebagaimana dinyatakan dalam al-Qur'an bahwa Risalah Muhammad Saw. untuk seluruh ummat manusia (Q. S. Saba, 34: 28) dalam berbagai aspek kehidupan (Q. S. al-Baqarah, 2: 208), bahkan rahmatnya harus dapat dirasakan oleh seluruh alam (Q. S. al-Anbiya', 21: 107).

${ }^{48}$ Abdullah Abdul Husein At-Tariqy, Al-Iqtishad Al-Islami, Ushuluhu wa Mubaun wa Ahdaf, Dar An-Nafais, Kuwait, $1999,282$.

${ }^{49} \mathrm{Abu}$ al-Muzaffar As-Sam'ani, Qawathi' al-Adillah fi al-Ushul, Beirut: Dar al- Kutub al-Ilmiyyah, t.t., II/343.

50 Dalam kerangka Sistem Bretton Woods mencapai kemaslahatan seperti itulah sebenarnya hukum Islam harus diarahkan. Seperti apapun keputusan hukum yang dikeluarkan, maka tercapainya kemaslahatan dan hilangnya kerusakan harus menjadi pertimbangan yang pertama dan utama. Pengembangan dan pembaharuan hukum Islam pada dasarnya juga merupakan upaya untuk menjadikan hukum Islam bisa mengakomodasi perkembangan zaman sehingga bisa mencapai kemaslahatan bagi manusia yang merupakan tujuan utama ditetapkannya hukum Islam. 
Krisis moneter yang berkepanjangan membuat kehidupan manusia semakin sempit dari limpahan rezki untuk tetap bertahan, seperti lantaran di-PHK, dan lain-lain. Faktor ekonomi merupakan faktor fundamental dalam menciptakan keamanan, kemakmuran dan kesejahteraan. Selain itu, faktor ekonomi menduduki posisi strategis dalam keberlangsungan keluarga. Kebelangsungan untuk membina keluarga dan menjaga keturunan dan generasi terbaik di masa yang akan datang.

Dengan disepakatinya Sistem Bretton Wood telah menjamin sistem perdagangan dan pembayaran yang terbuka sekaligus menyediakan perlindungan bagi stabilitas ekonomi global. Selain itu, sistem Bretton Wood sangat efektif dalam mengontrol konflik dan dalam rangka meraih tujuan-tujuan bersama yang telah dibuat oleh negara-negara bangsa.

\section{PENUTUP}

Berdasarkan penjelasan di atas, ketidakstabilan ekonomi global, harus diantisipasi dan diatasi dengan policy yang cepat dan tepat, karena dapat mengancam keberadaan alkulliyat al-khams yang harus dilindungi dalam pandangan Islam. Sistem Bretton Woods salah satu dari kesepakatan ekonomi yang tepat untuk membangun sistem ekonomi internasional (1944-1971), dan terbukti mampu mewujudkan stabilitas global dengan berbagai kesepakatan kebijakan dan regulasi internasional. Di samping itu, diperlukan upaya kongkrit untuk mewujudkan ekonomi politik Islam Internasional di tengah problematika keumatan yang terjadi akhir-akhir ini. Dengan melihat fakta dan realitas sekarang, maka ekonomi politik Islam Internasional menjadi sebuah keharusan dan keniscayaan, baik dalam skala regional dan internasional. Karena hal ini bisa menjadi jalan untuk meneguhkan posisi Islam sebagai rahmatan lil alamin. Islam sebagai value, harus terinternalisasi di dalam setiap decision dan policy yang menyangkut hajat hidup orang banyak. Ekonomi politik internasional menjadi posisi yang sangat strategis untuk menentukan kebijakan demi tercapainya stabilitas dan kemaslahatan global. Sistem Bretton Woods bisa menjadi sebuah "the inspired system" yang bisa menjadi pertimbangan untuk merumuskan arah dan strategi ekonomi politik Islam Internasional. Selain gold standard menjadi salah satu kesepakatan bretton woods dan stabilitas nilai tukar dengan diterapkannya fixed rate system, keteraturan perdagangan internasional dan banyaknya bantuan dana internasional untuk merekontruksi pembangunan di negara-negara korban perang menjadi penyebab lajunya pertumbuhan ekonomi global tertinggi sepanjang sejarah.

\section{DAFTAR PUSTAKA}

Anonim, "Eropa Usulkan Kembali Sisntem Bretton Woods, dikutip dari https://tekno.kompas.com/read/2008/10/17/04465814/eropa.usulkan.bretton.wo ods.ii?page=all diakses tanggal 19 Maret 2019

Arifin, Sjamsul (ed), Bangkitnya Perekonomian Asia Timur Satu Dekade setelah Krisis, Jakarta : PT Elex Media Kompotindo, 2008

As-Sam'ani, Abu al-Muzaffar, Qawathi' al-Adillah fi al-Ushul, Beirut: Dar al- Kutub al-Ilmiyyah, t.t, II/343.

Asur, Muhammad Thohir Ibnu, Maqashid al-Syari'ah al-Islamiyah, Tunisia: al-Syirkah Tunisia, 1978

At-Tariqy, Abdullah Abdul Husein, Al-Iqtishad Al-Islami, Ushuluhu wa Mubaun wa Ahdaf, Dar An-Nafais, Kuwait, 1999

Bordo, Michael D. and Owen F. Humpage, Federal Reserve Policy and Bretton Woods, Federal Reserve Bank of Dallas Globalization and Monetary Policy Institute Working Paper No. 206 http://www.dallasfed.org/assets/documents/institute/wpapers/2014/0206.pdf

Dahlan, Abdul Azis (ed), Ensiklopedi Hukum Islam, Jakarta: PT Ichtiar Baru Van Hoeve, tt 
Daniri, Ekonomi Syariah, Bretton Wods, KTT ASEM, dan AS, Republika, 3 Nopember 2008

Davies, Roy dan Glyn Davies, A History of Money from Ancient Time to Present Day, New York : Oxport University Press, 1996

Hadiwinata, Bob Sugeng, Politik Bisnis Internasional, Yogyakarta : Kanisius, 2002

Halwani, Hendra. Ekonomi Internasional \& Globalisasi Ekonomi. Edisi Pertama, Bogor : Ghalia Indonesia, 2002

Harinowo, Cyrillus, IMF Penanganan Krisis \& Indonesia Pasca-IMF, Jakarta : PT Gramedia Pustaka Utama, 2004

Hinkelman, Edward G., Dictionary of International Trade. $6^{\text {th }}$ Edition. Calfornia, World Trade Press, 2005

Huntington, Samuel P., dkk. Amerika dan Dunia, Jakarta : Yayasan Obor, 1989

Irwin, D.A, "Multilateral and Bilateral Trade Policies in the World Trading System : An Historical Perspective", in J. de Melo and A. Panagariya (eds), new Dimensions in Regional Integration, Cambridge : Cambridge University Press, 1993

Iswardono, Uang dan Bank, Yogyakarta : BPFE, 1996

Jackson, Robert \& Georg Sorensen, Pengantar Studi Hubungan International, Yogykarta : Pustaka Pelajar, 1999

Johnston, Thomas, The Depression Years, dikutip dari http://library.thinkquest.org/ 3483/Right/gd.html, diakses tanggal 5 April 2010.

Judesseno, Rimsky. K., Sistem moneter dan Perbankan di Indonesia, Jakarta : PT Gramedia Pustaka Utama, 2002

Judokusumo, Suherdi, Pengantar Derivatif dalam Moneter Internasional, Jakarta : Cikal Sakti, 2002

Kendleberger, Charles. P, The World in Depression 1929-1939, Berkeley : Calif, University of California Press, 1973

Kenen, Peter B., Managing the World Economy Fifty years after Bretton Woods, Washington, Institute for International Economic, 1994

Kenwood and Lougheed (1992), hlm. 286, dan Ashworth (1987), hlm.285. dalam Andrew G. Terborgh, "The Post-War Rise of World Trade: Does the Bretton Woods System Deserve Credit?", Working Paper No. 78/03, Department of Economic History London School of Economics, 2003

Kotz, David M., Terrence McDonough, and Michael Reich. Social Stuctures of Accumulation : The Polical Economy of Growth and Crisis, Cambridge : Cambridge University Press, 1994

Linder, Staffan. An Essay on Trade and Transformation. New York: Wiley, 1961

Pujiono, Arif. Dinar Dan Sistem Standar Tunggal Emas Ditinjau Menurut Sistem Moneter Islam, Jurnal Dinamika Pembangunan, Vol. 1 No. 2 / Desember 2004: 144 - 152

Pontoh,Coen Husein, Akhir Globalisasi : Dari Perdebatan Teori Menuju Gerakan Massa, Jakarta : C-Books, 2003

Rivai, Veithzal dan Andi Buchari, Islamic Economic : Ekonomi Syari'ah bukan Opsi tetapi Solusi, Jakarta : Bumi Aksara, 2009

Rothbard, Murray N., Apa yang Dilakukan Pemerintah terhadap Uang kita : Sebuah Pengantar Komprehensif Ekonomi Uang dari Mazhab Austria; terjemahan dan pengantar : Sukasah Syahdan; Edisi I, Jakarta : Granit, 2007

Spero, J.E. Political Realism in International Theory, Cambridge : Cambridge University Press, 1996

Wibisono, Sjamsul Arifin, Charles P.R. Joseph, Shinta Sudrajat, IMF dan Stabilitas Keuangan Negara : Suatu Tinjauan Kritis, Jakarta : PT Elex Media Kompotindo, 2007 
Ayif Fathurrahman

Winarno, Budi, Pertarungan Negara dan Pasar, Yogyakarta : MedPress, 2009. 